\title{
The Teacher's Desert Island Survival Kit
}

\author{
David Mendelsohn, Palmer Acheson, Janet Dawson, \\ Richard Handscombe, Maureen Hynes, \\ Francis Mangubhai, Jūra Seskus, H.H. (David) Stern
}

This paper consists of a brief introduction to a Symposium of the same title presented at the TESL Canada/TESL Ontario conference in Toronto in November 1985. In addition, it includes each panelist's list of the key items-their "survival kits"-which would be taken abroad if all they knew about their position was that they would be teaching adults.

Those of us involved in ESL/EFL teacher training are aware that a number of our students intend to teach abroad. One of the major preoccupations of both new and experienced teachers in planning for a posting abroad is, "What materials should I take with me?" However, it is still deplorably common that sponsoring agencies or the school in the host country provide little or no information about the students. Consequently, this question is often asked when all that the prospective teacher knows is that he or she will be teaching adults. In addition, this question of choosing useful, appropriate and effective materials is often constrained by two further factors. There has been a relative boom in the publication of ESL/EFL materials, a factor making extensive knowledge and selection from a wide range of materials difficult. In addition, teachers are often forced by financial limitations (personal or organizational) to ship or take only a small fraction of the materials that they feel they might need.

This Symposium was an attempt to find out how seven prominent people in the field of ESL/EFL would answer the question of selecting materials, considering the constraints mentioned above. They were asked to prepare a list of ten items that they would take with them, given only the information that they were going to teach adults abroad.

Presented here is a conclusion which draws together some of the common threads of the presenters' concerns in materials selection and preparation for an overseas posting, and a summary of each speaker's comments. Some speakers elaborated on and added to their printed lists, while others addressed different aspects and approaches to teaching abroad. However, all agreed that the exercise of compiling these lists was an engaging, demanding, and, at times, frustrating task, one which forms a cornerstone of responsibly training and preparing prospective EFL teachers. 


\section{Issues Raised by Presenters}

In the seven annotated bibliographies which follow, and in the participants' verbal presentations, certain themes recurred frequently, despite the apparent differences among the lists. These themes included:

1. It is essential to train for this profession before going. Despite the fact that certain agencies and countries are willing to hire untrained native speakers of English, it is the panel's opinion that training in TESL/TEFL is vital for such a job-perhaps even more vital than for ESL teaching in an English-speaking country. In his presentation, Handscombe emphasized the importance of the overseas-bound EFL teacher being properly trained. He made the point that training to be an English teacher to native speakers of English is not adequate.

2. Take materials that can be adapted. By including what Hynes refers to as prototypes for the adaptation and creation of materials, one increases the chances that these materials will more likely suit the local conditions and resources as well as the students' needs, interests, and language learning goals. Dawson hesitated in using a "classroom text" for the duration of the course as the result of bad experiences where one is often severely limited in the ways a book can be used. Ultimately, one ends up despising the book. Dawson also suggested that by avoiding classroom texts which were obviously culturally specific (i.e. Canadian, British, American), the possibilities for adaptation and expansion would be increased. It is important not to assume that materials that "worked" in a developed country will automatically work elsewhere.

3. Equip yourself with reference materials. Acheson stressed how essential good reference materials are, and how many and varied uses can be made of them, particularly as the teachers are bound to have to develop their own materials and will have them to fall back on when difficult language questions arise. Dawson, during her first experience as a very green EFL instructor in France, was asked by a student (there is one of these in every class) what a gerund was. Having been forced to run to a friend to help, she vowed never to be without a thoroughly comprehensive grammar text-hence the inclusion of Celce-Murcia \& Larsen-Freeman's The Grammar Book-An ESL/EFL Teacher's Guide. It is Stern's opinion that as a native speaker of an English-speaking culture, one should take a "Toronto box" so as to be able to teach within a cultural framework rather than within a vacuum. Handscombe noted that reference materials should include visual materials (e.g. The English Duden). Seskus astutely observed that most teachers who go overseas are in 
the early stages of their professional development, making appropriate resource and reference materials all the more important.

4. Take items that contribute to your mental health. Stern in particular stressed the need to take some things for the teacher's mental welfare. He stressed the fact, often overlooked in the excitement of being selected to teach abroad, that it can be a "lonely business".

5. Get as much information as you can about where you are going and who you are going to be teaching. Hynes believes that selfpreparation for going abroad to teach should begin with a seeking and demanding of more information and possibly, more support. She made the very helpful point that a lot of the background investigation should be done in Canada where we are familiar with the library system, know it is good and speak the language. Stern, among others, pointed out that it is vital that we try to understand the culture, the language, the educational system and the social system of the students. According to Hynes, another key consideration when seeking information prior to departure is the need to bear in mind the different reasons why students learn English in different countries: English may be the "lingua franca" in that country; it may be needed for technical or academic purposes; English may be needed to prepare students for further study; English may simply be a compulsory part of the curriculum; the learners may be destined to teach English.

6. Go with an open mind ready to propose innovation, but being mindful of the fact that cultural differences $d o$ exist and that "Rome wasn't built in a day". In addition, care must be taken not to assume that prior to the arrival of the overseas teacher, "darkness was on the face of the earth". Mangubhai concluded his presentation by expressing the hope that the foreigners coming to the island will realize that they have as much to learn as they have to teach, and that there are all sorts of different cultural conventions which they will have to adapt to. After all, it is the foreign expert who is "out of step", not the islanders. As well, patience with new and seemingly strange ways of the islanders is a sine qua non of success.

7. Be sure to encourage self-reliance and not to dominate. Mangubhai observed that there is a tendency on the part of the "foreign expert" not to involve the islanders-often the local staff will stand back and allow the expert to do this, but in such cases it is unlikely that the innovations will continue after the expert's departure.

8. Take full advantage of all local facilities and materials. Seskus pointed out that most "desert islands" that teachers go to are not barren, and that teachers should familiarize themselves fully with what is available locally, and utilize it to the maximum. 


\section{THE SEVEN SURVIVAL KITS}

\section{Palmer Acheson, Concordia University, Montreal}

Rationale for my Choice of Ten Software Items

Whether or not there are any existing materials on the desert island, I will want to write my own. Fact is more interesting than fiction, but I will need factual source materials which are contemporary and accurate. For materials-writing and answering questions, I will need good English language reference materials. In order to conduct a needs analysis with my students, and then to design a language teaching syllabus, I will need models to follow. For the production of neat and attractive learning materials, I will profit from some medium-high technology. For a variety of teaching techniques and procedures, it will be useful to have examples. To help my students with their listening skills, I will need samples of authentic spoken English. For general professional and intellectual stimulation, I will want to have a thoughtful book which examines the basic tenets of language teaching. Lastly, for spiritual nourishment, I will need something different from all the foregoing.

1. Mitchell, James (Ed. in Chief). (1983). (New rev. ed.; 1st pub. in 1970). Random house encyclopedia. New York: Random House. $(2,918$ pp. $\$ 135.00)$

This is the current edition of what is perhaps the best highly illustrated encyclopedia. It has 1,793 pages of self-contained twopage spreads covering the following seven themes: the universe; the earth; life on earth; man; history and culture; man and science; and man and machines. Key facts are covered alphabetically in 885 pages. There is a 49-page time chart and 82-page atlas. I would have preferred the World Book Encyclopedia (1985 ed.), because of its comprehensiveness and readability, but it has 22 volumes.

2. Quirk, Randolph et al. (1985). A comprehensive grammar of the English language. London: Longman. (1,792 pp. \$99.00)

As an arbiter of arguments, a reassuring hand on my shoulder as I devise materials, and quite readable as a text in its own right, I would invest in the most up-to-date, comprehensive and authoritative reference grammar yet published for the English language. Helpful with differences between British and American usage. If the desert island was once a British colony, its inhabitants may be confused by the differences between the English they learned and that spoken by the bringers of green manna.

3. Morris, William (Ed.). (1969). Houghton Mifflin Canadian dictionary of the English language. Markham, ON: Houghton Mifflin. (1,550 pp. \$19.95)

To accompany the reference grammar, I will need a reference 
dictionary. There are more comprehensive ones than my favourite, but I doubt that I will need their breadth of coverage. This has an ultra-clear typeface, instructive and attractive marginal illustrations, maps and diagrams, and a unique index of Indo-European roots. Eminently browsable. You might want to look at the Second College edition (1982) of the American version of this dictionary.

4. Proctor, Paul (Ed. in Chief). (1978). Longman dictionary of contemporary English. London: Longman. (1,303 pp. \$21.80)

As well as a reference dictionary for the materials-writing teacher, a pedagogical ESL dictionary is needed as a model of the kind of explanations needed by learners. "LDOCE" has spawned many offspring (the Longman dictionary of American English (1983) being the most interesting, with its integral workbook, study notes and composite pictures), but the parent volume remains the most comprehensive.

5. Munby, John. (1978). Communicative syllabus design. Cambridge: Cambridge University Press. (232 pp. \$21.85)

I will want to discover why my students want to learn English, and what kind of English I should teach them. This will be my model for conducting a needs analysis and devising a syllabus (of a general or specific nature) for my students. These are quite specialized activities, and I will need all the help I can get.

6. A (hard, if possible) disk for a good micro-computer with word processing and graphics applications and manual.

With this, I will be able to produce legible and attractive learning materials for my students, and later teach them to do the same. The bibliography you are reading was produced on an Apple Macintosh, using the Macwrite software program. The Macintosh would be my choice of a microcomputer to bring to the island, because of the speed with which I would be able to teach my students to use it. (I'm assuming there is electricity on the island!)

7. Rivers, Wilga M. \& Mary S. Temperley. (1978). A practical guide to the teaching of English as a second or foreign language. New York: Oxford University Press. (399 pp. \$15.95)

This is a good technique-level "cookbook" of procedures which have proven successful in many places with many students. There are other books which are more recent, and there are anthologies with more advice, but anthologies are rather incoherent. Until something a great deal better comes along, I will use this text as a source of ideas for my daily teaching.

8. A package of C-90 cassette tapes with a variety of recordings: songs, interviews, radio phone-in programs and general cultural programs that will not date too fast (e.g. CBC's Quirks \& Quarks; The Food Show; Ideas, etc.) 
I will use these for listening comprehension exercises, hoping to be able to record more authentic speech from my short-wave radio/ cassette recorder. My motto is: "Comprehension Precedes and Exceeds Production," so I will want to offer my students a great deal of active listening activities.

9. Stern, H.H. (1983). Fundamental concepts of language teaching. Oxford: Oxford University Press. (582 pp. \$25.95)

For general professional stimulation, this is the best current analysis of the source disciplines of our profession. It bears several careful readings. Try your hand at emulating some of the many carefully designed models placed throughout the book. From the bibliography of over 1,000 items, compile a list of books you will read when you return to Canada.

10. Adler, Mortimer J. \& Charles Van Doren (Eds.). (1977). Great treasury of western thought: a compendium of important statements on man and his institutions by the great thinkers in western history. New York: R.R. Bowker. (1,771 pp. \$65.00)

Teachers do not live by facts alone. We need comforting, thoughtful ideas on our human condition. For those people who are members of an organized religion, they will want to bring their scriptures. These are mine, and have uplifted my soul out of many a Slough of Despond. Here, also, are universally valid themes to discuss with advanced students.

\section{Janet Dawson, University of Western Ontario, London}

At times I felt this was the most difficult problem-solving and decision-making activity that I have ever been involved in as an ESL instructor. It was not easy to decide on just ten.

\section{METHODOLOGY}

1. Candlin, Christopher (Ed. \& translator). (1981). The communicative teaching of English-principles and an exercise typology. London: Longman Group Ltd.

Materials development and design can be the bane of many ESL/ EFL instructors' existence if there is not access to a reference and guide to assist them in the process. The Communicative Teaching of English provides the reader with information on: establishing objectives, form, function and strategy, theme-oriented English teaching, in addition to a complete exercise typology. By using this text, the task becomes easier and the materials designed more effective and successful.

2. Savignon, Sandra J. \& Margie S. Berns. (1984). Initiatives in com- 
municative language teaching. Reading, Mass.: Addison-Wesley Publishing Company.

The usefulness of this text lies in the range of topics discussed under the following headings: background perspectives, methods and materials and evaluation. It offers concrete examples of second language programs in different parts of the world and provides the reader with suggestions and advice for specific teaching situations. As a resource book its value lies in the diversity of the readings and the balance of methodology, linguistics, and materials design.

3. Yalden, Janice. (1983). The communicative syllabus: evolution, design and implementation. London: Pergamon Institute of English.

When faced with the daunting prospect of designing a language course, the EFL instructor needs a rock on which to build. The range and depth of this text offers a wealth of information-both theoretical and practical-to assist in this task. There are sections on: language teaching and theory, evolution of syllabus design, language program development and many others. If this text is used as a guide, the instructor has the necessary tools to design a course which meets the needs of the students.

\section{CLASSROOM TEXTS}

4. Maingay, Susan. (1983). Making sense of reading. London: Harrap (now distributed through Thomas Nelson).

In a reading text I look for variety of content and skill development tasks. Making Sense of Reading offers ten units, each concentrating on the development of a new reading skill. The use of authentic material and the accompanying activities are intended to encourage the students to be selective and also equip them to deal with the reading world beyond the classroom. The text links many of the units with suggestions for oral work, such as problem-solving, discussions, pair-work and class presentations.

5. Rost, Michael \& John Lance. (1984). Pairallels for pair work. Tucson, Arizona: Lingual House (text and tapes).

The plethora of listening materials currently on the market can be confusing when it comes to selecting a suitable text. Pairallels can, to a large extent, alleviate this confusion and provide the instructor with a well-organized and stimulating text. The success lies not only in the complete involvement of the students when using it, but also in the development of effective listening strategies coupled with cooperative language learning activities. The variety of topics and tasks extends far beyond the listening class.

6. Johnson, Keith. (1981). Communicate in writing. London: Longman Group Ltd.

One problem for the ESL/EFL writing instructor can be the 
limited range of material and topics available in one text. Given the usual diversity of students' interests and backgrounds, finding such a text can be difficult. Communicate in Writing (for me) solves some of these problems. It provides a solid framework for developing a writing course and steering both instructor and students in the right direction. The major divisions of the writing tasks: describing things and ideas, describing processes and events, developing an argument, are introduced by readings on a variety of topics.

\section{RESOURCE TEXTS}

7. Klippel, Friederike. (1984). Keep talking. Cambridge: Cambridge University Press.

Every ESL/EFL instructor's dream is to find a text which has more than a hundred communicative activities for the classroom and can also be used in a hundred different ways. Keep Talking is such a book. It offers so many activities and ideas that it would be difficult to use them all. An added advantage is the inclusion of worksheets which can be legally copied in any way one wishes.

8. Morgan, John \& Mario Rinvolucri. (1983). Once upon a timeusing stories in the language classroom. Cambridge: Cambridge University Press.

Ron Stevens, a consummate story-teller from Winnipeg, is responsible for my interest in this type of language activity. Having seen his success using this technique with university-bound ESL students, I can vouch for its impact in the second language classroom. This text provides the inexperienced story-teller (such as myself) with a wide variety of stories, ideas and activities.

\section{GRAMMAR TEXT}

9. Celce-Murcia, Marianne \& Diane Larsen-Freeman. (1983). The grammar book-an ESL/EFL teacher's course. Rowley, Mass.: Newbury House.

Despite the cost and the weight of this book, it is an excellent grammar reference for ESL/EFL instructors. While it is not ideal for classroom use, it enables the instructor to deal with the finer points of grammar and anticipate problems students might have. One valuable aspect of this text is the teaching suggestions which are made at the conclusion of each chapter. No ESL/EFL instructor should leave home without it.

\section{VISUAL MATERIAL}

10. Maley, Alan, Alan Duff \& Françoise Grellet. (1980). The mind's 
Eye. Cambridge: Cambridge University Press. (student's book, teacher's book)

As a source of ideas and suggestions for using visual material in the second language classroom, this text is a valuable resource. An extensive number of techniques and pictures are included in the book, thus providing the opportunity for a wide variety of collaborative activities. The cultural context which is apparent in many of the photographs affords an ideal basis for discussion, explanation and comparison.

\section{Richard Handscombe, Glendon College, York University, Toronto}

1. Britannica book of the year. Chicago: Encyclopaedia Britannica Inc.

Contains an immense amount of information on a huge variety of topics. At last I would have the time to catch up with the most recent year's activities other than my own (a marked contrast to Robinson Crusoe). But I would also have a resource book that would provide me with an almost infinite amount of material for intermediate and advanced levels.

2. The english duden: a pictorial dictionary. London: George G. Harrap. Latest revised edition.

As a passionate believer in the value of the visual but the possessor of negligible artistic skills, I would need a resource book with simple illustrations of the dugongs and postilions that would enhance our vocabulary studies. It would also enable me to recognise our rescue vessel as a gaff-rigged sloop rather than a ketch. Besides, it's a lot of fun.

3. Wright, Andrew. (1976). Visual materials for the language teacher. London: Longman. And reprints.

Successfully convinces me that even I can draw, given all that sand and a sharp stick.

4. The two-volume -with-magnifying-glass edition of the Oxford English dictionary, or Webster's third international.

When someone says "But surely postillion has two l's?", an appeal to authority will comfort us both.

5. Quirk, Randolph et al. (1972). A grammar of contemporary english. London: Longman. And reprints.

The modesty of the title, which still charms me, is in inverse proportion to the scope of the book, which I have always wanted to read.

6. A bundle of recent Life magazines.

I need a more coherent semantic than Duden provides, and more and better illustrations than I can get from Item 1 or create from Item 3. I also need materials that I can cut up without feeling pain. 
7. Hornby, A.S. (1975). Guide to patterns and usage in English. London: Oxford University Press. And reprints.

This remains one of the clearest teaching guides to English. It is eclectic, even to including "notional" methodology and material before it/they became so defined. A reminder that ours is quite an old profession.

8. Billows, F.L. (1977). The techniques of foreign language teaching. London: Longman. And reprints.

Almost as much an autobiography as a textbook, Billows' advice, outdated as it no doubt is in some places, remains both realistic and humane.

9. Finocchiaro, Mary. (1974). English as a second language: from theory to practice. New York: Regents. Another clear reminder of basic principles derived from long personal experience.

10. Brand, Oscar. (1961). Folk songs for fun. New York: Hollis Music, Inc. And reprints.

\section{Maureen Hynes, George Brown College, Toronto}

My assumptions in preparing this list are that the prospective EFL teacher will probably have to create or adapt classroom activities (possibly in conjunction with prescribed texts); may face the prospect of curriculum design, perhaps even the design of a teacher training course; and might, as well, be involved in test design. Consequently, rather than focussing on actual classroom texts, I have provided the names of texts that will afford rationales and quite a few prototypes of activities that will probably have to be adapted to suit local conditions and resources, the students' levels of proficiency, their needs and goals in language learning.

The books suggested, then, are divided into categories relating to grammar, methodology, skill areas, theoretical concerns and testing; but none is necessarily specific to any level of proficiency.

I have also assumed that the teacher already has a substantial monolingual dictionary (e.g., The Concise Oxford Dictionary, New Edition).

\section{GRAMMAR REFERENCE}

1. Celce-Murcia, Marianne and Diane Larsen-Freeman. (1983). The grammar book: an ESL/EFL teacher's course. Rowley, Mass: Newbury House.

Despite its prohibitive cost and rather disappointing suggestions for grammar teaching, the most accessible and comprehensible pedagogical grammar book; certainly more accessible than the equally expensive classic, R. Quirk et al. (1972). A grammar of 
contemporary English. London: Longman. A cheaper alternative to both these reference grammars is R. Quirk \& S. Greenbaum. (1973). A university grammar of English. London: Longman.

\section{STUDENT GRAMMAR TEXT}

2. Carroll, Washington Pollock. (1982). Communicate what you mean. Englewood Cliffs, N.J.: Prentice-Hall.

A thorough student exercise book, aimed at the higher levels of proficiency, but readily adaptable. A chief advantage is that each exercise is thematically united, rather than a collection of discrete sentences.

\section{METHODOLOGY}

3. Rivers, Wilga \& Mary S. Temperley. (1978). A practical guide to the teaching of English as a second or foreign language. New York: Oxford University Press.

Despite its date, a sound "cookbook" of techniques based on communicative teaching principles; useful for its taxonomies of classroom activities for various skill areas. If there is any reason to expect that you will be training non-native teachers, an up-to-date and useful methods text is Jane Willis. (1981). Teaching English through English. London: Longman.

\section{SPEAKING}

4. Klippel, Friederike. (1984). Keep talking: communicative fluency activities for language teaching. Cambridge: Cambridge University Press.

A vast compendium of very interesting communicative tasks at various ranges of proficiency levels.

\section{LISTENING}

5. Ur, Penny. (1984). Teaching listening comprehension. Cambridge: Cambridge University Press.

A "how-to" book on listening task design (with many examples) rather than a set of exercises for a particular level. Useful journal articles to supplement this text are: Richards, Jack C. (1983), Listening comprehension; approach, design and procedure. TESOL Quarterly 17:2 and Zhu Jiaju. (1984). Making use of news broadcasts. ELT Journal 38:4.

\section{READING}

6. Grellet, Françoise. (1981). Developing reading skills: a practical 
guide to reading comprehension exercises. Cambridge: Cambridge University Press.

Again, an excellent "how-to" book that focusses on clarifying the purposes of reading activities and their design, with many examples of exercises supplied.

\section{WRITING}

7. McKay, Sandra (Ed.). (1984). Composing in a second language. Rowley, Mass.: Newbury House.

A stimulating collection of articles on various theories, teaching strategies, discussions of program content and modes feedback and evaluation for a writing program; it also includes writing exercises for teachers and students at the end of each article.

\section{PRONUNCIATION}

8. Gilbert, Judy B. (1984). Clear speech: pronunciation and listening comprehension in American English. Cambridge: Cambridge University Press. (Teacher's \& student's manuals plus 2 tapes)

A course book that provides relatively interesting tasks on such aspects as stress, "English rhythm", reduction and the production of "clear sounds"-all in combination with some listening tasks.

\section{ENGLISH FOR SPECIFIC PURPOSES}

9. McDonough, Jo. (1984). ESP in perspective: a practical guide. London: Collins Educational Press.

A good background text for teachers about the field of ESP, the theory behind it, and practical suggestions for needs analysis, materials design, classroom implementation, evaluation, etc.

\section{TESTING, CURRICULUM DESIGN, SECOND LANGUAGE ACQUISITION THEORY}

10. Savignon, Sandra J. (1983). Communicative competence: theory and classroom practice. Reading, Mass.: Addison-Wesley.

A broad and thorough analysis of the theoretical background to language teaching methodology, with attention to curriculum design, classroom methodology and the design of communicative tests.

\section{IDIOMS AND CULTURE}

11. Adams, Thomas \& Susan R. Kuder. (1984). Attitudes through idioms. Rowley,-Mass.: Newbury House.

Although not a strict essential, this book is interesting in that 
it-finally!-incorporates a sound approach to the teaching of idioms through discussion of "cultural attitudes" (privacy, friendliness, honesty, independence, etc.) and cross-cultural comparisons.

\section{SUPPORT MATERIALS}

It might be useful-though not in keeping with the spirit of this exercise!- to provide a list of other materials and areas for a teacher to consider in preparing to go abroad to teach.

- $\quad$ songbooks and music tapes

- games and gamebooks

- a picture file

- a file of slides

- an atlas or map of the world

- a one-volume encyclopaedia

- a clipping file of magazine and newspaper articles on various themes, such as family, language, development, business, science, environment

- a National Film Board (NFB) catalogue if you are going to a country which has a Canadian Embassy stocking NFB films

- anthologies of literature, plays, short stories and poetry, e.g., M.H. Abrams et al. eds., The Norton Anthology of English Literature, Revised, Volume 2, New York: W.W. Norton \& Co.

- subscriptions to journals in the field, such as the TESL Canada Journal, the TESOL Quarterly, as well as to other magazines: The New Internationalist, The Manchester Guardian, Maclean's.

\section{Francis Mangubhai, University of the South Pacific and Ontario Institute for Studies in Education, Toronto}

Rather than making suggestions for "materials" for a survival kit, I have decided to suggest a list of attitudes and behaviours. They are not in any hierarchical order of importance.

1. Patience

- at the way things are done.

- people may operate on a different time scale; there are other rhythms than the tick of a clock.

2. Efficiency, which may be measured in terms of social rather than task outcomes.

3. Transplantation. Ideas, schemes transplanted from one context to another don't always work.

4. "Over-success". Nothing succeeds like success! Not always! Or how to ensure that introduced innovations continue after your departure. 
5. Festina lente! Tailor innovations at a level at which they can be absorbed.

6. Learning: a two-way street. Have an open mind; you may learn as much as you impart learning.

7. Acceptance (at times) of something one would not normally approve of.

8. To go native or not? That is the question.

9. Cultural sensitizing

- age and how it is viewed in the society.

- forms of address.

- Vive la différence! Or how the sexes interact in the society.

- yes = maybe; yes = no; no = maybe; no $=$ no.

- touching, personal space, etc.

- clothing.

10. Quirk, Randolph \& Sidney Greenbaum. (1975). A university grammar of English. London: Longman.

A handy reference book when second or foreign language learners ask awkward questions about the English language.

\section{Jūra Seskus, School of Continuing Studies, University of Toronto}

1. Maculaitis, Jean D'Arcy \& Mona Scheraga. (1981). "What to do before the books arrive (and after)". San Francisco: The Alemany Press.

Benefits both the new and the experienced teacher by suggesting techniques, methods for use in the ESL classroom which are practical, adaptable and fun.

2. A subscription to a fat, weekend paper with a colour supplement, e.g., Sunday New York Times, London Times, The Observer, Toronto Star. A local desert island English paper.

A must for realia: pictures for discussion and writing, reading materials, games, vocabulary work.

3. A shortwave radio/cassette player and blank tapes.

Necessary to obtain authentic listening, vocabulary and cultural input as well as specially prepared EFL programs such as Radio Canada and Voice of America and BBC EFL programs.

4. A good learner's dictionary (as opposed to a regular dictionary), e.g., Longman Dictionary of Contemporary English or Oxford Advanced Learner's Dictionary.

Definitions are understandable and appropriate for learners of English as a second or foreign language. Grammatical information is given along with examples of how the word can be used in a sentence. Usually illustrated, includes a pronunciation guide as well as synonyms and antonyms. 
5. Morley, Joan. (1979). Improving Spoken English. Ann Arbor: University of Michigan Press.

Contains both simple explanations and lots of practice material for pronunciation and indirectly for listening. Tapescripts are contained at back so can make own tapes if necessary.

6. Wright, Andrew, D. Betteridge \& M. Buckly. (1984). Games for Language Learning. (2nd ed.) Cambridge: Cambridge University Press.

Games for all skills: speaking, pronunciation, listening, reading, writing, vocabulary for all levels of proficiency.

7. Jones, Leo \& C. von Baeyer. (1983). functions of american english. New York: Cambridge University Press.

Mendelsohn, D., R. Laufer \& J. Seskus. (1984). Functioning in English. Toronto: Hodder and Stoughton Ltd.

Effective communication is part of social interaction. These books are modular in form and cover the basic talking needs of learners of English, i.e., to express themselves in English in varied and appropriate ways.

8. Thomson, A.J. \& A.V. Martinet. (1980). A practical english grammar. (3rd ed.). Oxford: Oxford University Press.

OR

Azar, Betty S. (1981). Understanding and using English grammar. Englewood Cliffs, N.J.: Prentice Hall.

The first is both a teacher reference book and an intermediate and higher student book. Two drawbacks: it is in British English and there are no exercises in it. In addition, it is necessary to buy accompanying exercise books.

The second is a student's reference and workbook and in North American English. However, it does not cover all the grammar points, especially more advanced items or items in greater depth.

9. Savignon, Sandra J. (1983). Communicative competence: theory and classroom practice. Reading: Addison-Wesley Publishing Co.

A reference book for the new teacher that covers theory and practice and including present trends in second language teaching, syllabus design, various activities and testing. A good introduction and a good read.

10. Bander, R. (1985). From sentence to paragraph. (2nd ed.). New York: Holt, Rinehart, Winston.

Works on writing beyond the level of the sentence and includes some vocabulary and grammar. Deals with connecting words, simple and compound sentences in addition to organization of paragraphs: topic sentences, controlling ideas, unity, coherence.

11. Graham, Carolyn. (1978). Jazz chants. New York: Oxford University Press. 
A personal favourite used for pronunciation, rhythm, and stress. Chants also give practice in different grammar points. A fun book to liven up even the worst of Friday afternoon blahs.

\section{H.H. (David) Stern, Ontario Institute for Studies in Education, Toronto}

1. Rubin, J. \& I. Thompson. (1982). How to be a more successful language learner. Boston, Mass.: Heinle and Heinle.

This well thought-out small book would enable me to discuss with my students in English working strategies for language learning and would pave the way for an independent and cooperative approach to ESL.

2. Toronto Box.

This is a home-made documentation kit I want to take with me. It contains various authentic items which would bring to my classes the living reality of a Canadian city which I know it would be difficult to get overseas: picture postcards, maps of Toronto, a TTC Guide, coins, paper money, stamps, University/College (York, U of T, OISE, Ryerson, Sheridan, etc.) bulletins, museum and store catalogues, sample daily papers, suburban Yellow Pages, personal letters and notes.

3. Video/Audio Box.

Another home-made kit with audio cassettes of recordings of CBC Metro Morning, Morningside, samples of David Schatzky's Noon Hour Phone-In Show, examples of news broadcasts and of As It Happens. Some audio cassettes of novels and short stories. Video cassettes of the National and the Journal.

4. Marsh, J.H. (Ed.). (1985). The Canadian encyclopedia. Edmonton: Hurtig Publishers.

ESL needs to be much more clearly related to cultural areas. It could be Britain, USA or Australia, as well as Canada. For Canada this encyclopedia would be an exceptionally valuable resource, worth its three volumes in paper weight. Moreover, it caters for every imaginable personal interest, and therefore combines the advantages of a regionally oriented information base with those of a general encyclopedia.

5. Longman dictionary of contemporary English. (1978). London: Longman.

A good dictionary is indispensible for reference. I find Longman's definitions and lay-out clear and simple. But I would be equally happy if the equivalent Webster or Oxford were washed ashore. 
6. Quirk, R., S. Greenbaum, G. Leech, \& J. Svartvik. (1985). A grammar of contemporary English. London: Longman.

Isolated from native speakers, I regard this as an essential reference work for current usage.

7. Celce-Murcia, M. \& D. Larsen-Freeman. (1983). The grammar book: an ESL/EFL teacher's course. Rowley, Mass.: Newbury House.

This work is an outstanding example of a pedagogical grammar I could use either for myself as a teacher or for other teachers to work with.

8-10. Desert island dictionary, grammar, and sociocultural guide.

As an ESL teacher overseas I would regard it as essential to become informed about the country, its life, and educational framework; also to study the home language (or languages) of the students I would be concerned with.

\section{CONCLUSION}

In conclusion, when accepting an EFL position abroad, one should bear in mind what our broader goal is: to extend the benefits that we enjoy-in this case, a language resource-to people in other countries.

Hynes sums this up very succinctly by arguing that it is our responsibility to ensure:

- that the process involves the participation of local people with a view to fostering self-reliance and independence;

- that the process integrates traditional with modern systems and methods ${ }^{1}$

- that the process is sensitive to the overall educational context

- that the process involves an accurate, sensitive in-depth investigation of the needs of the learners, the educational context and the host country in regard to language teaching and learning.

\section{NOTES}

1. For further information, see the following. Everett Rogers. (1976). Communication and development. Beverley Hills and London: Sage Publications. For an interesting discussion of this question in a Chinese context, see A. Maley. (1985). On chalk and cheese, babies and bathwater and squared circles: can traditional and communicative approaches be reconciled? In Larson, Judd and Messerschmitt. (Eds.). On TESOL '84. See also EFL for Development by David A. Cooke in this Special Issue of the TESL Canada Journal. 


\section{THE AUTHORS}

David Mendelsohn works at the University of Toronto, Palmer Acheson at Concordia University, Janet Dawson at the University of Western Ontario, Richard Handscombe at York University, Maureen Hynes at George Brown College, Francis Mangubhai at the University of the South Pacific and the Ontario Institute for Studies in Education (OISE), Jüra Seskus at the University of Toronto, and H.H. (David) Stern at the Ontario Institute for Studies in Education. 